\title{
MAPPING OF FOREST PLANTATION IN FOREST RESEARCH INSTITUTE, DEHRADUN USING IKONOS DATA
}

Kotresha K.* \& Indra Jit Singh ${ }^{* *}$

\begin{abstract}
The forests are the source for many our essentiol requirements such as fuel wood, timber, raw materials for paper and above all, it helps us to maintain the $\mathrm{CO}_{2} / \mathrm{O}_{2}$ balance in nature. Sustainable forest management requires reliable information. The aerial photographs and GIS data information can generate various scenarios for forest management plans of local, national and global scales.

IKONOS is the world first one-meter resolution commercial imaging satellite. The interpretation of aerial photograph and satellife data are of great benefit for neighboring and regional land use, forest mapping, to find change defection and are effective for large area inventories, forest planning etc.

In the present study, an attempt has been made to classify the FRI forest in to 11 -forest cover and land use classes. The major chunk of forest consists of Pine forest, which occupy 94.04 ha and 743.20 ha of the total forest area during 1973 and 2001, respectively. It is followed by mixed forest with 53.31 ha (1973) and 5.50 ha (2001), and Teak with
\end{abstract}

* Department of Botany, Karnatak Science College, Dhorwad, Karnataka - 580001. Email: kotresh_sk@yahoo.com

** Scientist-SF, Forestry and Ecology Division, IIRS (National Remote Sensing Agency), Department of Space, Government of India, 4th Kalidas Marg, Dehradun, Uttaranchal - 248001 
17.68 ha (1973) and 8.49 ha (2001). The Sol forest showed an increase in forest cover from 4.83 ho (1973) to 5.39 ha (2001). Similarly Eucalyptus forest showed a forest cover of 1.84 ha in 2001, which was not seen in the year 1973 (Table 4.2). The constructions also showed an increase from $3.14 \mathrm{ha}$ in 1973 to $24.68 \mathrm{ha}$ in 2001 and in case of nursery and miscellaneous (scrub), there has been increasing in total forest cover.

The IKONOS image of 2001 surprisingly showed no change in Champa forest cover. Decrease in forest cover of Teak, Sal, and Mixed forest must have been due to felling of tress for logging purposes and their forest cover might have been replaced by scrub vegetation (miscellaneous), construction, Eucolyptus plantation and nursery.

The results of the present project showed changes in terms of area coverage by the forest types, which helps us to assess future prospects of the forestland use pattern.

\section{Introduction}

Forest refers to an area with different types of vegetation, but predominated by trees. It forms an important natural resource and plays a vital role in environmental conservation. The forests are the source for many our essential requirements such as fuel wood, timber, raw materials for paper and above all, it helps us to maintain the $\mathrm{CO}_{2} / \mathrm{O}_{2}$ balance in nature. Forest also provide habitat for numerous animal species and thus, forms a complex but stable ecosystem, which is self-perpetuating with respect to flora and fauna.

The forest are exposed to many human inferferences, as a result, they are fast depleting from all parts of the world. It is now well established that the decrease in forest has resulted into a number of serious environmental problems such as soil erosion, flood, pollution, which have seriously affected the biodiversity in different parts of the world.

After the Rio Conference in 1992, however, the environmental consciousness has led to the formulation of many national and global policies for sustainable development of renewable resources. Sustainable forest management requires reliable information. The aerial photographs and GIS data information can generate various scenarios for forest management plans at local, national and global scales.

India is one of the few countries in the world, which has adopted a forest policy as early as in 1894 AD, which was revised in 1952, and in 1988. The main objective of the National Forest Policy, 1988 is protection consenvation and development of 
forest. Accordingly one third of country's land is required to be under forest cover but State Forest Report (SFR) 1997, indicates that only 19.27\% of the total geographical area is under the forest cover. India with an area of 328.8 million hectare is being seventh largest country in the world and second most populated country supporting 950 million human populations.

Further with continuous growth in human population, there is a great pressure on forest vegetation leading to its deforestation and depletion. In addition forest areas are continuously being cleared for alternative uses like rehabilitation, Agriculture, Mining, etc. causing many environmental problems. This has threatened the very existence of many valuable biodiversity in the world.

The study area of Forest Research Institute (FRI), Dehradun (Uttaranchal) is situated between $30^{\circ} 90^{\prime} 55^{\prime} \frac{1}{2}$ and $30^{\circ} 21^{\prime} 161 / 2 \mathrm{~N}$ latitude and $77^{\circ} 58^{\prime} 40^{\prime} \frac{1}{2}$ and $78^{\circ}$ $011^{\prime} 001 / 2 \mathrm{E}$ longitude in an elevation of $663 \mathrm{~m}$ above sea level and is flanked between Himalayas and Siwalik range. It has average annual rainfall of $2200 \mathrm{~mm}$.

The IKONOS satellite system was initiated as the commercial remote sensing system, which provides good quality data of the globe. The data frequency can encompass all degree of forest dynamics anywhere on the earth. The satellite sensors have spectral range between $450.750 \mathrm{~mm}$ with $4 \mathrm{MS}$ I PAN Band and $1.4 \mathrm{~m}$ GSD with 1-3 day revisit along with $13 \mathrm{Km}$ swath widths. Digitization of vegetation cover using two sets of imagery can easily lead us to change detection. Using this technique, it is revecled that the forest in India is loosing tree cover at the rate of I-3 million ha a year.

\subsection{Modern Technology for Survey and Mapping of Vegetation of the Forest}

Scientific survey of forest is a pre-requisite for proper planning and development, as it provides both goods and services to the mankind. One may adopt either the conventional methods of ground survey or use an advanced and sophisticated technique of remote sensing. The former has many limitations and may not sometimes fulfill the required closer and vigilant monitoring, while the later has many advantages and is widely used.

The advance technique has been applied to map the forest resources in different part of our country in recent time (Roy 1985, 1987, 1991, Roy ef al. 1985, Sudhakar et al., 1992, Madhavan et al. 1991, Khuswaha ef al., 2001). It has also been seen that there are large variations on the occurrence, nature, structure, composition 
and density of forest with respect to climate, soil, phisiography etc. (Rao, 1990). Thus it is essential to map the forest cover regularly at a short interval of time (Dhalival, 1995).

Remotely sensed data with the help of modern technique is acquired either directly on the photo film or on media like high-density digital tape (HDDT), optical disk etc. In the former case the product is called aerial photographs while in later case as image or imagery.

\subsection{Uses of Aerial Photographs}

The aerial photo-interpretation is a proven technique extensively used for forest resource management. The use of aerial photographs in forestry falls in to three distinct categories viz. forest mapping, inventory and management. Using aerial photographs forest type identification for different parts of India has been done by different workers (Sharma, 1986; Tomar, 1968, 1970 etc.).

\subsection{Uses of Satellite Images}

The images data from high-density digital tape obtain from satellite are transferred on the film to generate hard copy photoproducts. The satellite remote sensing became operational after launching of Earth Resources Technology Satellite (ERTS) in early seventies. This was renamed as LANDSAT-1 by United States. India had developed its own space technology and launched its IRS series of satellites, the first being the IRS-1A launched in 1988. Currently, IRS-P6 is operational providing high quality AWiFS, LISS III and IV data. Satellite image interpretation in forestry and other natural resources of India started in 1973 by the Space Application Centre (SAC) at Ahmedabad. The National Remote Sensing Agency (NRSA) was established in 1975 at Hyderabad for operation of remote sensing based natural resources assessment and monitoring.

\subsection{IKONOS}

IKONOS is the world first one-meter resolution commercial imaging satellite launched on September 24, 1999 from Vandenberg Air Force base, California, USA. The spatial resolution of IKONOS image is $82 \mathrm{~cm}$ in Nadir viewing. It is like an aerial photograph (Tanka and Sugimura, 2001). The IKONOS satellite system was initiated as the commercial remote sensing system, which provides good quality data of the Globe (Ramnathan, 2001). The data frequency can encompass all degree of forest dynamics anywhere on the earth. The satellite sensors have spectral range between 
450-750 mm with 4 MS 1 PAN Band and 1-4 m GSD with 1-3 day revisit along with $13 \mathrm{Km}$ swath widths (Plate -1$)$.

\subsection{Satellite Data Interpretation}

Satellite data, since beginning is being interpreted by visual and digital means. Many studies have been carried out using visual interpretation for mapping and monitoring of forest vegetation at different levels. The Nationwide Forest Cover Mapping using 1972-75 and 1980-82 Landsat Multi-Spectral Scanner System (MSS) data on 1:1 million scales has been carried out by NRSA in 1983. The Forest Survey of India has been carrying out the task of nationwide mapping of forest at 1:250000 scale satellite imagery by visual interpretation (FSI, 2001).

Digitization of vegetation cover using two sets of imagery can easily lead us to change detection. Using this technique, it is revealed that the forest in India is loosing tree cover at the rate of 1-3 million ha a year (Dhaliwal et al., 1995) and that out of seventy five million ha of forest, forty million ha are now without tree cover (Choudhary, 1992).

The interpretation of aerial photograph and satellite data are of great benefit for neighboring and regional land use, forest mapping, to find change detection and are effective for large area inventories, forest planning etc.

\subsection{Remote Sensing and Geographic Information System (GIS) in Forestry}

Remote sensing is a tool to derive information from distance while GIS is to integrate the information on natural resources and environment of the earth which helps to develop decision support system for generating information for management. Most GISs deal with the data in two spatial dimension and are organized which can yield useful knowledge in the form of coloured maps, images, graphics and information tables. It is thus computer-based technology characterized by a specific hardware and software, which permits simultaneous storage, management and analysis of data along with its geographic location. It is a spatial data based management system (Jordan, 1989). The important role of remote sensing and GIS on forestry and ecology are vegetation and soil mapping, monitoring of biotic pressure on land degradation, mapping and monitoring of biodiversity, change detection in vegetation cover, detection of forest fire, insect infestation, diseases etc. 


\subsection{Study Area}

The study area of Forest Research Institute (FRI), Dehra Dun (Uttaranchal) was established in 1960 . The area is situated between $30^{\circ} 90^{\prime} 551 / 2$ and $30^{\circ} 21^{\prime} 16^{\prime} 1 / 2 \mathrm{~N}$ latitude and $77^{\circ} 58^{\circ} 40^{1} 1 / 2$ and $78^{\circ} 01^{\circ} 001 / 2$ E longitude in an elevation of $663 \mathrm{~m}$ above sea level and is flanked between Himalayas and Siwalik range. It has average annual rainfall of $2200 \mathrm{~mm}$; the relative humidity is well over 50 per cent except in the month of May and June while the temperature varies from maximum of $44^{\circ} \mathrm{C}$ in the month of June to a minimum of $2.4^{\circ} \mathrm{C}$ in January. The months of December and January experience frosty weather. The soil is porous and well drained. The climate of the campus is congenial to the flora and fauna. Nearly 1,400 species of indigenous and exotic flora are found in the campus (Plate- II).

\section{Materials and Methods}

The following materials and methods were employed to achieve the above objective of the present investigation.

\subsection{Table Showing the Details of the Satellite Data Product}

\begin{tabular}{|l|c|}
\hline Satellite & IKONOS2 \\
\hline Sensor & Optical sensor assembly (OSA) \\
\hline Data product & Standard IKONOS FCC \\
\hline Date & 4 December 2001 \\
\hline Spatial resolution & $4 \mathrm{~m}$ \\
\hline Swath width & $11 \mathrm{Km}$ \\
\hline Pointing capacity & $\pm 30^{\circ}$ \\
\hline Revisittime & $1-3$ days \\
\hline
\end{tabular}


2.2 Table Showing the Information on Aerial Photograph

\begin{tabular}{|l|l|}
\hline Year & 1976 \\
\hline Scale & $1: 5000$ \\
\hline Sensor & Panchromatic B/W \\
\hline Size of photograph & $18^{\prime} 18 \mathrm{~cm}$ \\
\hline Number & $\begin{array}{l}706 \mathrm{~A} / 15-12,706 \mathrm{~A} / 14-13,706 \mathrm{~A} \\
14-15,706 \mathrm{~A} / 15-10,706 \mathrm{~A} / 14 \\
\end{array}$ \\
& $11,706 \mathrm{~A} / 16-5,706 \mathrm{~A} / 16-6$ \\
\hline
\end{tabular}

\subsection{Reconnaissance Survey}

Since the investigators were stranger to the area, reconnaissance survey was first undertaken. This is to get familiar with the picture of the study area. Character identification of the various forest types, species composition, species phenology, crown density etc. has initially undertaken. It also includes the coordination of FRI forest range staff.

\subsection{Analytical Tool and Computer Hardware/Software}

The following analytical tool and computer facilities were used in the plantation mapping;

$>$ ERDAS Imagine 8.7

$>$ Arch-view $3.2 \mathrm{~A}$

$>$ Compaq colour computer with accessories

$>$ Windows NT and Windows 2000 operating system

$>$ MSOffice (Word, Excel and Power Point)

\subsection{Field Instruments}

Digital Camera, GPS 


\subsection{Computer Analysis}

Spatial data in the form of maps were scanned using hp scanner and transferred to computer readable digital map. The digital maps were import it to ERDAS IMAGINE and rectification process were done using the software. The image-to-image registration was done by obtaining a transformation with all points on one image to points to another image. To accomplish these GCPs, pairs of GCP (Geocoordination Points) that are known to be some physical locations on both images are located. The polynomial transforms, which describes how the uncorrected image date must be wrapped over the raster data, is based on ground control points.

At the IKONOS and aerial photographs scenes of projected area were rectified separately. The rectified digital maps were imported to ARCVIEW in order to digitize and generate various theme layers visualized forest cover type map, forest density type map etc. The only screen digitization was done in ARCVIEW was used for presses of cleaning and editing, and all the concern attributes were assigned to each cover class. Transformation processes, which are important for analysis operations, were carried out in ARCVIEW using geographical Lat. / Long projection system. All the theme layers were assigned proper colour and legend and stored in GIS for further analysis. (Fig 2.1, 2.2 and 2.3).

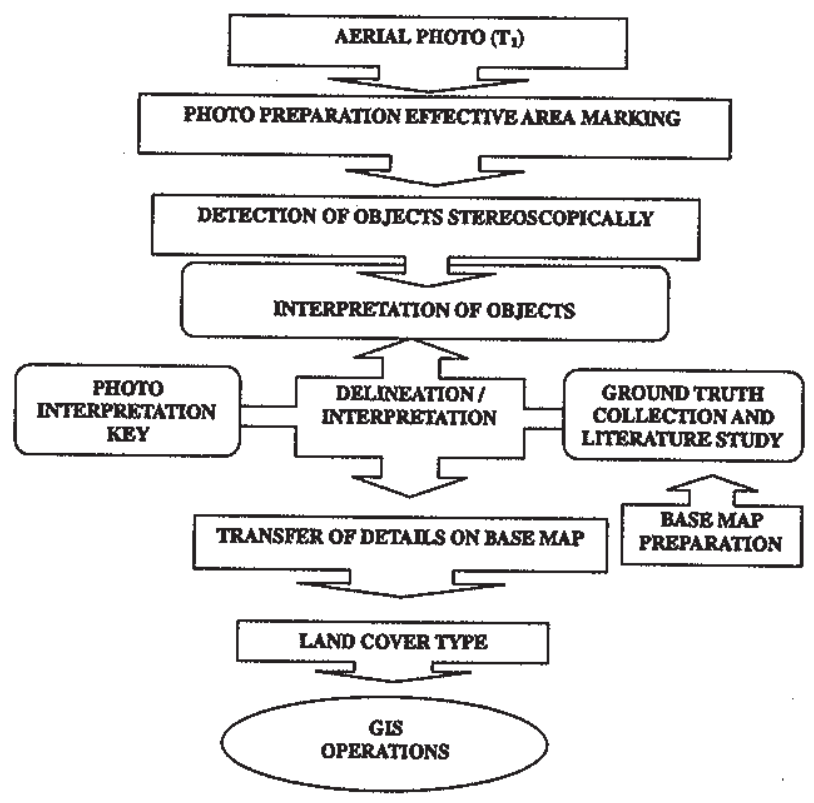

Fig 2.1: Flow Diagram showing the Methodology (a) 


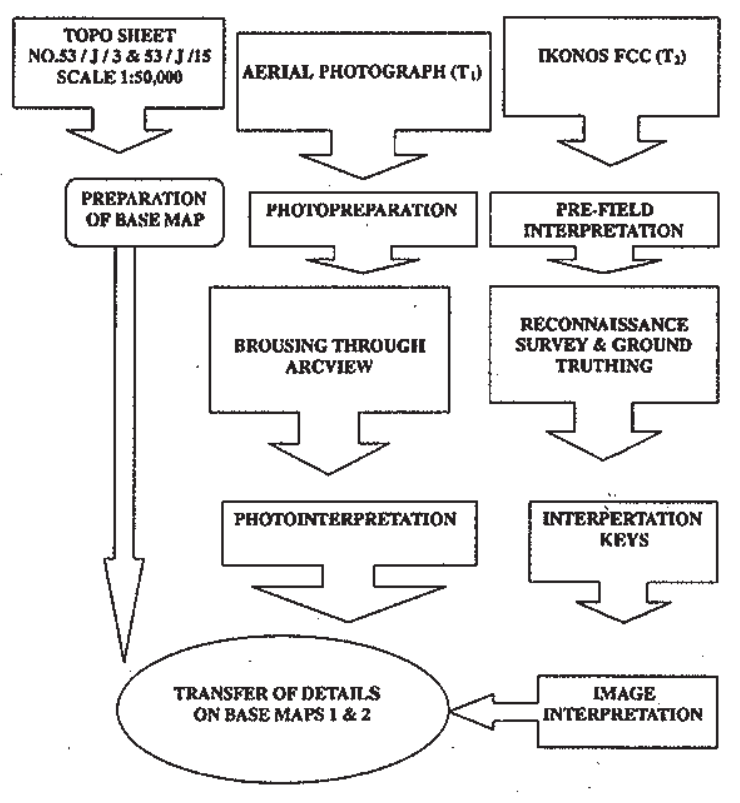

Fig 2.2: Flow Diagram showing the Methodology (a)

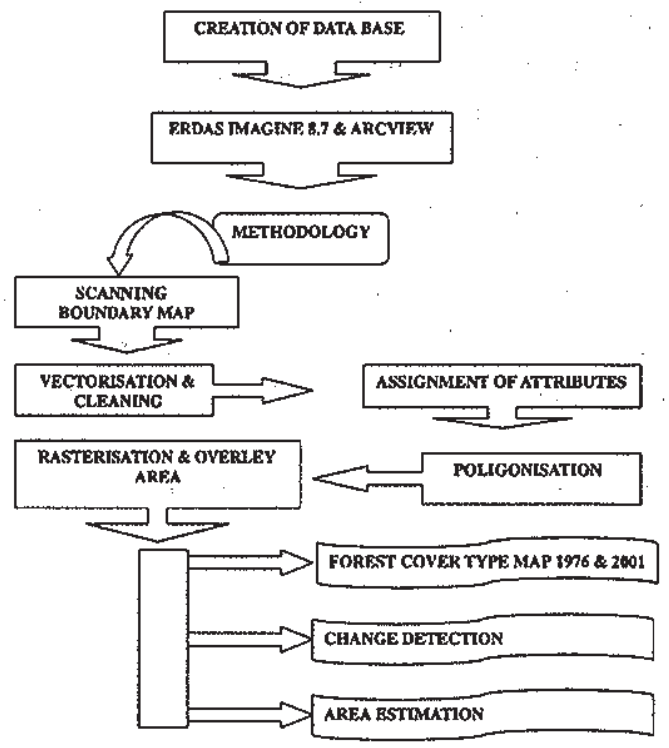

Fig 2.3: GIS Analysis (c) 


\section{Results and Discussion}

The present study focuses on methodological aspect followed with two main procedures, that is, firstly preparation of forest cover and land use mapping by visual interpretation on aerial photographs of 1973 and IKONOS image of 2001 and secondly creation of various theme layers in the GIS domain. This study has achieved a number of resulis and outputs based on well defined assumptions and objectives. A brief discussion on the findings of the study has been listed and mentioned below.

\section{Forest Cover Type Mapping}

In the present study, an attempt has been made to classity the FRI forest in to 11 forest cover and land use classes, which is shown in Table 3.1 with the symbol. The major chunk of forest consists of Pine forest, which occupy 94.04 ha and 143.20 ha of the total forest area during 1973 and 2001 , respectively. It is followed by

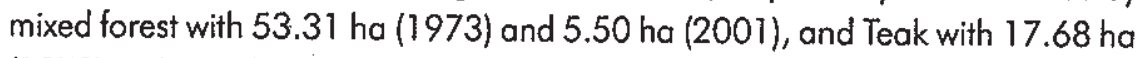
(1973) and 8.49 ha (2001).

The Sal forest showed an increase in forest cover from $4.83 \mathrm{ha}(1973)$ to $5.39 \mathrm{ha}$ (2001). Similarly Eucalyptus forest showed a forest cover of 1.84 ha in 2001, which was not seen in the year 1973 (Table 3.3). The constructions also showed an increase from 3.14 ha in 1973 to 24.68 ha in 2001 and in case of nursery and miscellaneous (scrub), there has been increasing in total forest cover.

The IKONOS image of 2001 surprisingly showed no change in Champa forest cover. Decrease in forest cover of Teak, Sal, and Mixed forest must have been due to felling of trees for logging purposes and their forest cover might have been replaced by scrub vegetation (miscellaneous), construction, Eucalyptus plantation and nursery. Table 3.2 shows plant biodiversity in the FRI area. 
Table 3.1: Symbol for different forest cover types and land use.

\begin{tabular}{|l|c|}
\hline Forest Cover Type & Symbol \\
\hline Teak Forest (Tectona grandis) & $\mathrm{TF}$ \\
\hline Sal Forest (Shorea robusta) & $\mathrm{SF}$ \\
\hline Plantations & $\mathrm{Pl}$ \\
\hline Pine Forest (Pinus roxburghii) & $\mathrm{PF}$ \\
\hline Open Area (Without Vegetation) & $\mathrm{OA}$ \\
\hline Nursery & $\mathrm{Ns}$ \\
\hline Mixed Forest & $\mathrm{MF}$ \\
\hline Miscellaneous (Scrub) & $\mathrm{Mi}$ \\
\hline Champa Forest (Michelia champaca) & $\mathrm{CF}$ \\
\hline Constructions & $\mathrm{Cs}$ \\
\hline Eucalyptus Forest & $\mathrm{EF}$ \\
\hline
\end{tabular}

Table 3.2 The following species have been identified in the FRI during reconnaissance survey.

\begin{tabular}{|l|l|l|l|}
\hline Sl. No. & Species & Sl. No. & Species \\
\hline 1 & Chukrasia sp. & 13 & Acrocarpus fragrifolius \\
\hline 2 & Cassia fistula & 14 & Michelia champaca \\
\hline 3 & Ficus bengalensis & 15 & Morus alba \\
\hline 4 & Cinamomum camphora & 16 & Bambusa sp \\
\hline 5 & Eucalyptus & 17 & Litchi chinensis \\
\hline 6 & Dalbergia sissoo & 18 & Syzygium cumini \\
\hline 7 & Powlonia & 19 & Cupressus sp. \\
\hline 8 & Shorea robusta & 20 & Araucaria cummighamai \\
\hline 9 & Terminalia melocarpa & 21 & Agathis robusta \\
\hline 10 & Tectona grandis & 22 & Texodium mucronatum \\
\hline 11 & Acacia catechu & 23 & Pinus roxburghii \\
\hline 12 & Anthocarpus kadamba & 24 & Podocarpus sp \\
\hline
\end{tabular}


Table 3.3: Data Showing the Different Forest Cover Types

\begin{tabular}{|l|c|c|c|}
\hline Forest Cover Type & $\begin{array}{c}\text { Area T1 } \\
\text { (ha) }\end{array}$ & $\begin{array}{c}\text { Area T2 } \\
\text { (ha) }\end{array}$ & $\begin{array}{c}\text { Change } \\
\text { (ha) }\end{array}$ \\
\hline Teak Forest (Tectona grandis) & 17.68 & 8.49 & -9.19 \\
\hline Sal Forest (Shorea robusta) & 4.83 & 5.39 & 0.56 \\
\hline Plantations & 8.99 & 4.06 & -4.93 \\
\hline Pine Forest (Pinus roxburghii) & 94.04 & 143.20 & 49.16 \\
\hline Open Area (With out vegetation) & 85.97 & 54.26 & -31.71 \\
\hline Nursery & 2.64 & 6.04 & 3.40 \\
\hline Mixed Forest & 53.31 & 5.50 & -47.81 \\
\hline Miscellaneous (Scrub) & 10.28 & 27.43 & 17.15 \\
\hline Champa Forest (Michelia champaca) & 0.42 & 0.41 & -0.01 \\
\hline Constructions & 3.14 & 24.68 & 21.54 \\
\hline Eucalyptus Forest & 0.00 & 1.84 & 1.84 \\
\hline Total & 280 & 281.30 & 0.00 \\
\hline
\end{tabular}

\section{Conclusion}

$>$ It is concluded from the present study that mapping of the forest type and land use pattern could be assessed from the "Aerial photograph and IKONOS data".

$>$ Ground truthing has helped to identify the Forest types and Species composition of the area.

$>$ The species composition and change matrix of the forest cover from 1973 to 2001 of FRI has been worked out. 
$>$ The results of the present project showed changes in terms of area coverage by the forest types, which helps us to assess future prospects of the forestland use pattern.

\section{Acknowledgements}

The authors wish to thank the Authorities of Karnatak University, Dharwad and Forestry \& Ecology Division, IIRS (National Remote Sensing Agency), Department of Space, Government of India, 4th Kalidas Marg, Dehradun, Uttaranchal . 248001 for the basic facilities, encouragement and support during this investigation.

\section{References}

1. Bharat, R.P. (1999) Management Plan for the Dehra Dun Forest Division, Uttar Pradesh $1999-2000$.

2. Daliwal, S.S. (1995) Mapping and Monitoring of Reserve and Protected Forest in Patiala District Using Remote Sensing of Environment with Special Emphasis on Green Revolution ed., by Balder Sahai.

3. FSI, 2001. State of Forest Report (2001) Forest Survey of India, MOEF, Govt of India, Dehra Dun.

4. Joseph, George (2003) Fundamentals of Remote Sensing, University Press, Hyderabad, pp 433

5. Jordan, Glen A. (1989) Making GIS work in Forest Management.

6. Kushwaha, S.P.S., Munkhtuya, S. and Roy P.S. (2001) Geospatial Modeling for Goral habitat evaluation. Journal of Indian Society of Remote Sensing, Vol.28 (4), 293-303

7. Lillesand, T.M. and Kiefer, R.W. (1987) Remote Sensing and Image Interpretation, $3^{\text {td }}$ Ed., John Wiley and Sons, Inc.

8. Madhawan, Unii, N. V., Jadhar, P.S., Tiwari R.N., Sudhakar A.K.S., Ranganath B.K. and Dabral M.K. (1991) RS -14 Applications in Forestry. Current Science Vol. 63 (3\&4), 188. 192.

9. National Remote Sensing Agency (1983). Nation-wide mapping of forest and non-forest areas using Landsat FCC for the period 1972-75 and 1980-82. Project report Vol.1, p 34

10. Ponwall, M.C. (1997) Prioritisation of Probable Sites for Forest Plantation-A Remote Sensing and Geographical Information System Approach. Remote Sensing for Natural Resources.

11. Romnathan, Sugumaran, (2001) Forestland cover classification using statistical and artificial neural network approaches applied to IRS LISS-Ill sensor. Geo Corto International. Vol. $16(2), 37-42$

12. Rao, U. R. (1990) Space and Forest Management. Proc. 41 IAE Cong. Dresden, Germany. P.!. 
13. Roy, P.S. (1993) Forest type mapping and monitoring in Varatang Forest Division (Andaman Island), Photonirvachak.

14. Roy, P.S. (1987) Montane vegetation stratification through digital processing of Landsat MSS data, Geo Carto International, Vol. 1, 19-26.

15. Roy, P.S., Ranganathan B.K., Diwakar P.G., Vohra T.P.S., Bhen S.K., Singh I.J. and Pandian V.C. (1991) Tropical forest type mapping and monitoring using remote sensing. Intemational Journal of Remote sensing. Vol, 12 (11), 2205-2225

16. Sharma, M.K. (1986) Remote Sensing and Forest Surveys. Intemationol Book Distributors, Dehradun

17. Tanka and Sugimura (2001) A New Frontier of Remote Sensing from IKONOS Image. International Journal of Remote Sensing. Vol. 22 (1), 1-5.

18. Tomar, M. S. (1968) Mannual of Photo-interprefation in Tropical forest (Kerala and Tamil Nadu), Pre-investment Survey of Forest Resources, Dehra Dun.

19. Tomar, M. S. (1970) Manual of Photo-interpretation for Southern Tropical Deciduous Forest of East Godavari, A.P., Pre-investment Survey of Forest Resources, Dehra Dun. 